Ethiopian Journal of Environmental Studies \& Management 8(3): 283 - 289, 2015.

ISSN:1998-0507

doi: http://dx.doi.org/10.4314/ejesm.v8i3.5

Submitted: January 12, 2015

Accepted: March 26, 2015

\title{
ENVIRONMENTAL STUDIES OF THERMAL POWER STATION EFFLUENTS: A CASE STUDY OF EGBIN THERMAL STATION, IKORODU
}

\author{
${ }^{*}$ AKINYOMI, A., ${ }^{1}$ BABAJIDE, A.I. ${ }^{1}$ AND OKORO, H.K. ${ }^{2}$ \\ ${ }^{1}$ Department of Chemistry, Faculty of Science, University of Lagos, Akoka, Lagos State \\ ${ }^{2}$ Environmental-Analytical and Material Research Group, Department of Industrial \\ Chemistry, Faculty of Physical Sciences, University of Ilorin, P.M.B.1515, Ilorin, Nigeria
}

\begin{abstract}
This research work was carried out to investigate the level of pollution from the Egbin thermal station and their significant effects on the environment. Samples were collected in duplicate at four different locations. The major parameters investigated on analysis include heavy metals, anions and physico-chemical parameters. BUCK 210 VGP flame atomic absorption spectrophotometer (AAS) model was used for the metal analysis. Iron, zinc and copper are the predominant metals in the samples while chromium was not detected at some of the sampled locations. The average concentrations of zinc, iron, copper and chromium were $0.153 \mathrm{mg} / \mathrm{L}, 3.635 \mathrm{mg} / \mathrm{L}, 0.088 \mathrm{mg} / \mathrm{L}$ and $0.080 \mathrm{mg} / \mathrm{L}$ respectively. The effluents average for temperature, $\mathrm{pH}$, and conductivity were $34^{\circ} \mathrm{C}, 6.98,445 \mathrm{~S} / \mathrm{cm}$ respectively. Hardness, TS, TDS, SS, Alkalinity, acidity, $D O, B O D_{5}$, phosphate, chloride and sulphate concentrations were $47.5 \mathrm{mg} / \mathrm{L}, 98.75 \mathrm{mg} / \mathrm{L}, 68.5 \mathrm{mg} / \mathrm{L}, 30.25 \mathrm{mg} / \mathrm{L}, 31.90 \mathrm{mg} / \mathrm{L} .6 .44 \mathrm{mg} / \mathrm{L}$. $5.76 \mathrm{mg} / \mathrm{L}, 9.61 \mathrm{mg} / \mathrm{L}, 0.18 \mathrm{mg} / \mathrm{L}, 40.37 \mathrm{mg} / \mathrm{L}$ and $67.41 \mathrm{mg} / \mathrm{L}$ respectively. The high concentration of iron, zinc and some of the physicochemical parameters determined in the samples from the Egbin treatment plant and from the point of discharge showed that the effluents from the Egbin thermal station contribute to the pollutants load in the receiving lagoon.
\end{abstract}

Key Words: Effluents, Metals; AAS, Pollutants, Thermal station

\section{Introduction}

Our total environment is made up of land, water, air and living things. Environment is an all-encompassing made up of the basic components created pure for human use and absolutely indispensable. The inter-relationship of these components constitutes the ecosystem (Ademoroti, 1996) Land, water, air and living things are very vital Water is necessary for domestic uses like drinking, cooking, washing, etc. For agricultural uses like cropping, flock watering, fish culturing and nursery of seedlings. Air is also very important. We breathe in air and out, enhance respiration

*Corresponding Author: Akinyomi, A. 283

in living things and above all, no one can survive without air (Ademoroti, 1996, Okoro et al., 2012). In the context of the environmental impact assessment, the environment broadly includes the ecosystem (biotic and abiotic components), physical, social economic, cultural and political dimensions in the various interactions and interrelationships. Examples of environmental considerations are air and water quality, erosion generation and control, natural hazards, land use planning, site selection and design, pollution and impact of the environment on people's values and activities. In the quest

Email: ddelex@yahoo.com 
for industrial development and invented technologies for processing raw materials for utilizable finished products.

Metals are mined for various uses, mineral oil is mined for energy supply, synthesized organic and inorganic fertilizers are made, synthesized pesticides and herbicides for good productivity of crops, synthesized textiles, detergents and soaps for cleaner and faster washing of the textiles are produced. These explain the interactions and impacts of man on the environment (Umeh and Uchegbu, 1997). One of the major issues in the world today is environmental pollution; industrialization is one of the major sources of pollution (Fatoki et al., 2012; Okoro et al., 2012, Okoro et al., 2013b). In addition, thermal power station also causes environmental pollution. Soil serves as the main sources of trace and toxic elements for plant as a micronutrients and as well as pollutants (Rind et al., 2013). Sediment particles are made up of materials derived from rock, soil and anthropogenic sources (Okoro et $a l ., 2014)$. The source of trace and toxic elements alters their behaviour in soils and therefore controls their bioavailability to some extent (Rind et al., 2013). Fine particles have high specific areas that retain high amounts of metals (Wang et al., 2006; Okoro et al., 2013)). Moreover, the primary route of human exposure to these potentially toxic elements $(\mathrm{Cd}, \mathrm{Zn}, \mathrm{Cu}, \mathrm{Fe}$ and $\mathrm{Cr}$ ) can be attributed to the soil contamination. This study was carried out in order to investigate the impacts of thermal power station effluents on Egbin environment.

\section{Study Area}

Egbin Thermal Power Station is the largest power generating station in Nigeria with an installed capacity of $1320 \mathrm{MW}$ consisting of 6 Units of $220 \mathrm{MW}$ each. The station is located at Egbin, near Ijede Town-about $40 \mathrm{~km}$ North East of the city of Lagos in Ikorodu Local Government Area, it is situated on a low land and bounded by the Lagoon to the South, Agura/Gberigbe to the North and Ijede town to the West. The spot "Egbin" was a hamlet for peasant fishermen and farmers but was displaced to give way for the project. The first unit of the plant was commissioned in July 1985, while the last was commissioned in September 1986. The station is of reheat type with high intermediate low pressure impulse reaction turbine design and a hydrogen cooled generator. Egbin power station is located on latitudes $06^{\circ} 33^{\prime} 35^{\prime \prime} \mathrm{N}$ and $03^{\circ} 33^{\prime} 38^{\prime \prime} \mathrm{N}$ and logititudes $003^{\circ} 36^{\prime}$ $5^{\prime \prime} \mathrm{E}$ and $003^{\circ} 36^{\prime} 53^{\prime \prime} \mathrm{E}$. It is a selfcontained gas and oil fired steam electric generating station.

\section{Materials and Methods}

Water samples were collected in duplicate in acid pre-washed 2-litre polyethylene bottles from four different locations and sediments at two of the locations (the discharge point and $200 \mathrm{~m}$ downstream of the discharge point). The samples were collected from; the effluents treatment plant, the discharge point, $200 \mathrm{~m}$ from upstream, $200 \mathrm{~m}$ downstream of the discharge point. Detailed record of every sample collected was done by attaching and appropriately inscribed label showing the site, time and method of collection.

Pre-Treatment of Samples and Preservation

To prevent or reduce change in quality of the water samples, some of the physicochemical parameters were determined insitu while others were carried out shortly after collection in the laboratory. The samples were stored in a refrigerator and the temperature kept below $4^{\circ} \mathrm{C}$ prior to further analysis.

\section{Physico-Chemical Parameters} Determination

The $\mathrm{pH}$ of the water samples was determined in-situ using electronic $\mathrm{pH}$ meter digital model. Buffer solutions of $\mathrm{pH}$ 4 and $\mathrm{pH} 9$ were used to calibrate the equipment. The temperature of the water samples was determined in-situ using a Gallenkamp Griffin thermometer having a 
calibration from $0^{\circ} \mathrm{C}$ to $360^{\circ} \mathrm{C}$. The thermometer was placed vertically with the bulb containing the mercury immersed in the sample. It was allowed to stand until a steady reading was obtained. The conductivity was determined directly from the various water samples by using a Philips PW 9505 conductivity meter. The reading was recorded in $\mu S / \mathrm{cm}$.

\section{Total Solids (TS) and Suspended Solids (SS)}

A clean dish was dried at $105^{\circ} \mathrm{C}$ in oven until a constant weight was obtained and cooled to $25^{\circ} \mathrm{C}$ in the desiccators and the weight recorded was Wo. $100 \mathrm{ml}$ of water sample was measured into the dish and evaporated to dryness on a stream bath and dried at $105^{\circ} \mathrm{C}$ in the oven for about $1 \mathrm{hr}$. The dish was placed in the desiccators and cooled to room temperature and weighed. It was returned to the oven, dried further for about 20 minutes and re-weighed after cooling to $25^{\circ} \mathrm{C}$. This was repeated until the dish plus residue has constant weight recorded as WT. The weight of the dish was subtracted to obtain the weight of the residue.

For, Suspended solids determination, a pre-weighed filter paper was placed on holder and washed with $200 \mathrm{ml}$ of distilled water. $100 \mathrm{ml}$ of the water sample was placed into it and filtered. The filter paper was carefully removed after filtration and dried for 1 hour at $105^{\circ} \mathrm{C}$, cooled to room temperature in the desiccators and weighed. The drying cycle was repeated until constant weight was obtained. Total Dissolved Solid (DS) were obtained by the difference between the total solids and suspended solids (DS $=\mathrm{TS}-\mathrm{SS}$ ).

\section{Total Alkalinity and Hardness Determination}

The total alkalinity was determined by titration with a standard solution of hydrochloric acid. $100 \mathrm{ml}$ of the water sample was pipette into clean conical flask, three drops of phenolphthalein indicator was added to check for presence of carbonate and hydroxide alkalinities at the initial stages of the titration. There was no change in colour of the samples. Three drops of methyl orange indicator was then added and titrated further until the colour changed from yellow to brick red. The total hardness was determined by titration with Ethylene diamine tetra-acetate (EDTA) using Eriochrome black $\mathrm{T}$ as indicator and a mixture of borax, sodium hydroxide and sodium sulphide

\section{Acidity and Dissolved Oxygen Determination}

Acidity was determined by titration with a standard solution of sodium hydroxide. $100 \mathrm{ml}$ of the water sample was pipetted into clean conical flask, two drops of phenolphthaline indicator was added and titrated against $0.01 \mathrm{M} \mathrm{NaOH}$. The end point was obtained when the colour changed to pink. Water sample was collected in clean DO bottles and filled to the brim to exclude air. $1 \mathrm{ml}$ of $\mathrm{MnSO}_{4}$ and $1 \mathrm{ml}$ of alkaline-iodide-azide was added and mixed by inverting the bottle a few times. The precipitate was left to settle. $2 \mathrm{ml}$ concentrated $\mathrm{H}_{2} \mathrm{SO}_{4}$ was subsequently added and the content mixed to totally dissolve the precipitate. $50 \mathrm{ml}$ was taken into a conical flask and titrated immediately against standard sodium thiosulphate until the first disappearance of blue colour using 2 drops starch indicators.

Biochemical Oxygen demand. The dilution water was first prepared by adding $4 \mathrm{ml}$ each of phosphate buffer, $\mathrm{FeCl}_{3}$, $\mathrm{CaCl}_{2}, \mathrm{MgSO}_{4}$ and $\mathrm{NH}_{4} \mathrm{Cl}$ to four litres of distilled water. $100 \mathrm{ml}$ sample was placed into $1000 \mathrm{ml}$ standard volumetric flask and made up to volume with dilution water. 250 $\mathrm{ml}$ each was placed in a transparent DO bottle and a brown DO bottle. Also, the blank was prepared, which contained only the dilution water. The dissolved oxygen was immediately determined in the former using the procedure outlined above and the later incubated at $20^{\circ} \mathrm{C}$. On the fifth day, the DO was also determined. For anions determination, the following anions was 
determined; Chloride, sulphate, nitrate, phosphate according to standard method.

\section{Metals Determination}

The BUCK 210 VGP flame atomic absorption spectrophotometer (AAS) model was used to determine the metals. The water samples and sediments were first digested using concentrated $\mathrm{HNO}_{3}$ before analysis. $100 \mathrm{ml}$ of the water sample was taken and $5 \mathrm{ml}$ concentrated $\mathrm{HNO}_{3}$ was added. It was digested on a heating mantle inside a fume cupboard for about 30 minutes until the sample was reduced to about half its volume by evaporation and then made up to volume with distilled water. Also, $1.0 \mathrm{~g}$ of the sediment was weighed and $5 \mathrm{ml}$ of concentrated $\mathrm{HNO}_{3}$ added. This was digested as above for about 30 minutes and made up to $50 \mathrm{ml}$ mark with distilled water. The blank was also prepared in the same manner. The samples were subsequently analysed using AAS for zinc, copper, iron and chromium at each respective wavelengths.

\section{Results and Discussion}

Effluents from the Egbin thermal power station were investigated. The results of the physico-chemical analysis show that all the parameters analysed for were detected in all the samples. The $\mathrm{pH}$ values of the samples tested were below 7.2, varying between 6.80-7.12. The mean $\mathrm{pH}$ of all the water samples at 6.98 was within the WHO standard range of water for domestic use and also within the FMEnv effluent limit. The temperature of the water was recorded between $30-38^{\circ} \mathrm{C}$. The mean temperature of the water samples at $34^{\circ} \mathrm{C}$ was within the FMEnv effluent limit. High values at the effluent treatment plant indicated that the increased temperature observed in the lagoon emanated from the station.

The conductivity of the water samples varied between $164 \mu \mathrm{S} / \mathrm{cm}-600 \mu \mathrm{S} / \mathrm{cm}$. The conductivity values are useful indication of ionic solutes present. The results showed that the downstream discharge point had the highest concentration of solutes. The hardness of the water samples can be classified as soft since the concentration falls within the range of 0.60 (Graham and Welch, 1996). The mean hardness of all the water samples of $47.50 \mathrm{mg} / \mathrm{L} \mathrm{CaCO}$ fell within the WHO standards of water for domestic use as shown in Table 2.

The total alkalinity of the water samples varied between 30-33 mg/L $\mathrm{CaCO}_{3}$. The phenopthaline value for the samples tested was zero, indicating that both carbonate and hydroxide alkalinities were absent in the samples. The alkalinity present was due to the bicarbonate ions. This is indicated by the $\mathrm{pH}$ values, which were all less than 7.2. The mean value of all the water samples of $31.90 \mathrm{mg} / \mathrm{L} \mathrm{CaCO}_{3}$ was within the WHO standards of water for domestic use in Table 2. The acidity of the water samples varied between $6.0-6.90 \mathrm{mg} / \mathrm{L} \quad \mathrm{CaCO}_{3}$. This also conforms to the $\mathrm{pH}$ values obtained. The results of the DO, BODs, TS, SS, TDS, phosphate, chloride and sulphate. The analysis for DO is a key test in water pollution control activities and waste treatment process control. The DO for the water samples varied between 5.08-6.50 $\mathrm{mg} / \mathrm{L}$. The BODs detection level was between $8.0-11.11 \mathrm{mg} / \mathrm{L}$. The mean values for total solids, suspended solids and total dissolved solids range between 40-182 $\mathrm{mg} / \mathrm{L}$, 14-48 $\mathrm{mg} / \mathrm{l}$ and $20-134 \mathrm{mg} / \mathrm{L}$ respectively. The results show that water samples from the downstream of the discharge point has the highest values and this can be attributed to the domestic and economic activities in the area. The anions, phosphate, chloride and phosphate, chloride and sulphate, analysed in the water samples range between $0.33-0.342 \mathrm{mg} / \mathrm{L}, 37.49$ $42.99 \mathrm{mg} / \mathrm{L}$ and 48.20-74. $88 \mathrm{mg} / \mathrm{L}$ respectively which were within the FMEnv effluents limits. The samples from the downstream of the discharge point has the highest concentration of phosphate which is likely due to human activities like laundry with detergents which was common in the area. 
The average values were fell within WHO standards of water for domestic use and FMEnv effluents limits. The results of heavy metals show that; Zinc, iron, copper and chromium were present in the water samples at all collection sites at concentration ranges of $0.04-0.44 \mathrm{mg} / \mathrm{L}$, $3.295-4.023 \mathrm{mg} / \mathrm{L}, 0.057-0.157$ and nd-0.08 $\mathrm{mg} / \mathrm{L}$ respectively. Iron was the most predominant as it was found in all the water samples and at high concentration. Zinc concentration was very high in the samples from the effluent treatment plant, when compared to the other water samples. Iron concentration was highest in the samples from the downstream of the discharge point. Copper concentration was highest in the samples from the discharge point and lowest in the samples from the downstream of the discharge point. Zinc, iron, copper and chromium were all present in the sediment collected at the discharge point and downstream of discharge point at concentration range of $\mathrm{Zn} ; 0.0023-0.0081$ $\mathrm{mg} / \mathrm{g}, \mathrm{Fe} ; 0.9041-2.1011 \mathrm{mg} / \mathrm{g}, \mathrm{Cu} ; 0.0105-$ $0.0204 \mathrm{mg} / \mathrm{g}$ and Cr; ND- $0.0065 \mathrm{mg} / \mathrm{g}$ respectively. Iron concentration was highest in the sediments collected while zinc and chromium concentration were the lowest. Zinc efficiency is a particularly widespread micronutrient in wheat and this leads to severe depressions in wheat production and nutritional quality of grains (Graham and Welch, 1996; Graham et al., 1992). Iron and Zinc concentration were higher in the sediment samples collected at the treatment plant and at point of discharge than other sampled locations and this shows that effluents from the station contributes to the pollutants load of the receiving lagoon. Iron had highest average concentration in the sediments while chromium had the lowest average concentration. The values recorded for $\mathrm{Cr}$, $\mathrm{Fe}$ and $\mathrm{Zn}$ in this study was lower than the value recorded in a related studies carried out by Rind et al. (2013).

Table 4: Comparative assessment of the physico-chemical parameters and average concentrations of metals analysed in the samples collected at the Egbin thermal station versus some other known standards.

\begin{tabular}{llll}
\hline Metals & $\begin{array}{l}\text { Average values obtained } \\
\text { in ETPS samples }\end{array}$ & $\begin{array}{l}\text { FMEnv Limits/ } \\
\text { Standards, } 1991\end{array}$ & $\begin{array}{l}\text { WHO standards of water } \\
\text { for domestic uses } \\
(\mathrm{mg} / \mathrm{L})\end{array}$ \\
\hline Temperature & $34^{\circ} \mathrm{C}$ & $\begin{array}{l}<40 \text { OC within } 15 \text { meters } \\
\text { of outfall }\end{array}$ & - \\
$\mathrm{pH}$ & 6.98 & $6.00-9.00$ & - \\
Conductivity & $445 \mu \mathrm{S} / \mathrm{cm}$ & - & - \\
Hardness & 47.50 & - & $100-500$ \\
Alkalinity & 31.90 & - & - \\
Acidity & 6.44 & - & - \\
DO & 5.76 & - & - \\
BODs & 9.61 & 50.00 & - \\
TS & 98.75 & - & - \\
SS & 30.25 & 30.00 & - \\
TDS & 68.50 & 2000.00 & - \\
Phosphate & 0.18 & 5 & $200-600$ \\
Chloride & 40.37 & 200.00 & - \\
Sulphate & 67.41 & 600.00 & $5.0-15.0$ \\
Zinc & 0.153 & $<1$ & - \\
Iron & 3.635 & $5-20$ & $0.05-1.50$ \\
Copper & 0.088 & $<1$ & - \\
Chromium & 0.080 & $<1$ & - \\
\hline
\end{tabular}




\section{Conclusion}

From the results obtained, it was discovered that the Egbin Thermal power station effluents contributes to the pollutants load of the Lagos lagoon. For the heavy metals such as chromium, copper, iron and zinc, anions and physicochemical parameters determined, the Egbin thermal power station effluents showed high concentrations. As with most forms of pollution, sub lethal concentrations of heated water can be beneficial, as well as harmful, depending on the physiological state of the affected organism. It is evident from the study and literature that slight increase in temperature can stimulate feeding, growth, and overall general activity. Temperature increases of about $10^{\circ} \mathrm{C}$ and above can cause sufficient stress in living organisms at the lagoon. Fish will be killed when the station is temporarily shut down or major fluctuations in current patterns. High concentrations of heavy metals in the sediments can be harmful to fish and other organisms in the Lagos lagoon due to bioaccumulation in the fatty tissues of the organisms, and when consumed by man have fatal effects and seriously affect the ecosystem. Therefore, the high concentration of metals and some of the physic chemical parameters determined in the samples from the Egbin thermal station effluents may pose a significant threat to aquatic life in the Lagos lagoon.

\section{References}

Ademoroti, C.M.A. (1996). Environmental chemistry and Toxicology; Foludex Press Ltd, Ibadan

Fatoki, O.S., Okoro, H.K., Adekola, F.A., Ximba, B.J. and Synman, R.G. (2012). Bioaccumulation of Metals in black mussels (Mytillus galloprovincialis) in Cape Town Harbour, South Africa, The
Environmentalist, 32: 48-57. DOI 10.1007/s 10669-011-9370-5.

Graham, R.D and Welch RM. (1996). Breeding for staple food crops with high micronutrients density. International Food Policy Research Institute, Washington, DC.

Graham, R.D, Ascher, J.S. and Hynes, S.C. (1992). Selecting zinc-efficient cereal genotypes for soils of low zinc status. Plant Soil, 146: 241-250.

Lehoczky, E., Szabo, L., Horvath, S, Marth, P. and Szabados, I. (1998). Cadmium uptake by lettuce in different soils. Communications in Soil Science and Plant Analysis, 162(7): 487-500.

Moir, A.M and Thornton, I. (1998). Lead and cadmium in urban allotment and garden soils and vegetables in the United Kingdom. Environmental Geochemistry and Health, 11:113119.

Okoro, H.K., Fatoki, O.S., Adekola, F.A., Ximba, B.J. and Synman, R.G. (2012). A Review of Sequential Extraction and Instrumental Techniques for Heavy Metals Speciation in Soil and Sediment Matrices, Open Access Scientific Reports.1(3):181-189, DOI: 10.4172/Scientific reports.181.

Okoro, H.K., Fatoki, O.S., Adekola, F.A., Ximba, B.J., Snyman, R.G. and Mdokwana, B.W. (2013): The Effect of Particle Sizes on Metal Accumulation in the Marine Sediments of Cape Town harbour, South Africa, Journal of the North Carolina Academy of Science, 129(3): 115-125.

Okoro, H.K., Fatoki, OS., Adekola, F.A., Ximba, B.J. and Snyman, R.G. (2013). Physico-chemical characteristics and One year monitoring of heavy metal pollution in Seawater from Cape Town Harbour 
and their Seasonal Variation, Fresenius Environmental Bulletin, Germany. 22(10); 2855-2866.

Rind, AM., Matoi, G.M. and Hullio, A.A. (2013). Impacts of Jamshoro thermal power station on soil of the surrounding area. Ind. J. Sci. Res. \& Tech., 1(2): 65-71.

Reilly, C. (1991). Metal contamination of food. $2^{\text {nd }}$ edition, Elsevier Applied Science, London
Umeh, L.C and Uchegbu, S.N. (1997). Principles and procedures of Environmental impact assessment; Computer Edge Publishers, Lagos.

Wang, W.X. and Chen, C. (2006). Biosoption of heavy metals by Saccharomyces cerevisiae. A review. Biotechnology Advance, 24: 427-454. 